
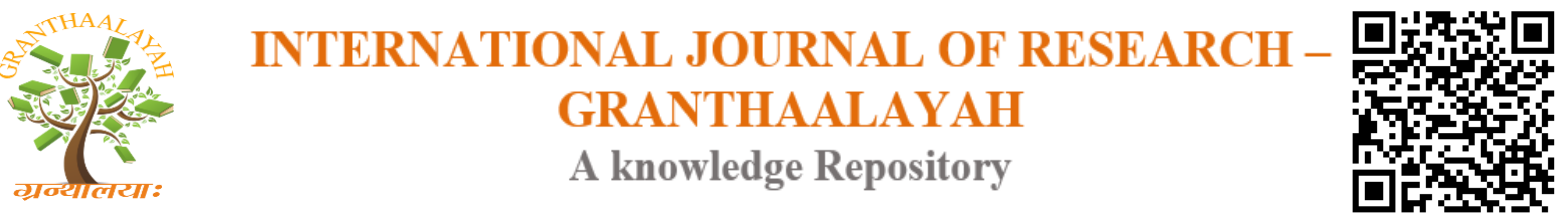

Science

\title{
PREVALENCE OF BOVINE FACIOLOSIS IN HALABA MUNICIPAL ABATTOR SOUTHERN ETHIOPIA
}

\author{
Muna Abdella ${ }^{1}$, Wubit Tafese Mhatebu ${ }^{* 2}$ \\ ${ }^{1,}{ }^{* 2}$ School of Veterinary Medicine, Jimma University, PO.box 307 Jimma, ETHIOPIA
}

DOI: https://doi.org/10.29121/granthaalayah.v4.i11.2016.2423

\section{ABSTRACT}

A cross-sectional study was carried out from November 2015 to march 2016 on bovine fasciolosis, to assess the abattoir based prevalence, predominant species of bovine fasciolosis and associated risk factors of the disease in cattle slaughtered in Halaba municipal abattoir. A total of 384 cattle were examined using post mortem examination. Infection rates were (3.64\%), 2.34\%, $2.08 \%$, and $1.82 \% \mathrm{~F}$. gigantic, $\mathrm{F}$. hepatica, mixed and immature respectively with the overall prevalence of $9.88 \%(38)$. F. gigantic was found to be the most prevalent species in cattle of the study area. Multivariable logistic regression analysis showed that the risk of fasciola infection was significantly higher in poor body condition animals than in medium and good body condition animals ( $p<0.05)$. However, in terms of age, sex and breed, no statistically significant difference was found between infected animals $(p>0.05)$.The present study showed that bovine fasciolosis is one of the important pathogens in cattle in the study area and warrants appropriate disease prevention and control measures and further epidemiological investigations to determine the different agro ecological risk factors on the occurrence of the disease.

Keywords:

Abattoir; Bovine; Fasciolosis; Halaba; Postmortem; Prevalence.

Cite This Article: Muna Abdella, and Wubit Tafese Mhatebu, "PREVALENCE OF BOVINE FACIOLOSIS IN HALABA MUNICIPAL ABATTOR SOUTHERN ETHIOPIA" International Journal of Research - Granthaalayah, Vol. 4, No. 11 (2016): 82-91.

\section{INTRODUCTION}

Ethiopia is believed to have 49.3 million cattle which is the largest livestock populationin Africa, yet produces insufficient animal protein and other livestock products to meet the demand of fast growing human population. The contribution of livestock industry to the national economy is considerably less than its tremendous potential. Among many constraints that made the livestock sector marginal is due to prevalent of different diseases, malnutrition, and management constraints. Parasitism represents a major obstacle to the development of the sector [13]. Fasciolosis is a worldwide parasitic disease and common in ruminants, especially in cattle, 
buffaloes, sheep, goats, and swine. It occasionally affects humans. Once ingested, parasites migrate through the liver parenchyma to reach the bile ducts. The disease is responsible for considerable economic losses in the cattle industry, mainly through mortality, liver condemnation, reduced production of meat, milk, and wool, and expenditures for anthelmintic $[22 ; 20]$.

The geographical distribution of trematode species is dependent on the distribution of suitable species of snails. The genus lymnaea in general and L. trancatula and L. natalensis in particular are the most common intermediate hosts for $F$. hepatica and $F$. gigantica respectively. F.hepatica has a cosmopolitan distribution, mainly in temperate zones, while $F$. gigantica is found in tropical regions of Africa and Asia. Different works so far conducted in Ethiopia reported variable prevalence rates of bovine fasciolosis in different localities of the country. $F$. hepatica was shown to be the most important fluke species in Ethiopian livestock with distribution of over three quarter of the nation except in the arid north-east and east of the county. The distribution of $F$. gigantica was mainly localized in the western humid zone of the country that encompasses approximately one fourth of the nation. In Ethiopia $F$. hepatica and $F$. gigantica infections occur in areas above 1800 m.a.s.l. and below 1200 m.a.s.l respectively which has been attributed to variations in the climatic and ecological conditions such as rain fall, altitude, temperature and livestock management system $[30 ; 24 ; 20]$. Diagnosis of fasciolosis may consist of tentative and confirmatory procedures. A tentative diagnosis of fasciolosis may be established based on prior knowledge of the epidemiology of the disease in a given environment, observations of clinical signs, information on grazing history and seasonal occurrence. Confirmatory diagnosis; however, is based on demonstration of fasciola eggs through standard examination of feces in the laboratory; postmortem examination of infected animals and demonstration of immature and mature flukes in the liver. The latter is helpful in deciding the intensity of infection. For chronic fasciolosis, confirmatory diagnosis could easily carried out by coproscopicexamination employing sedimentation technique. Fasciola eggs have high specific gravity and sedimentation is used. As fasciola eggs may be confused with Paramphistomum eggs, addition of methylene blue in the feacal suspension will facilitate ease identification by providing a blue and contrasting microscopic field [15].

Because epidemiology of fasciolosis is dynamic and may change with years [16], it is important to monitor its development to determine trends in prevalence. There is no study performed on occurrence of bovine fasciolosis in the study area. Therefore, this study was conducted in Halaba municipal abattoir to: Determine the abattoir based prevalence of Bovine fasciolosis in Halaba area, Identify the predominant species of bovine fasciolosis and Assess associated risk factors.

\section{MATERIALS AND METHODS}

\subsection{STUDY AREA}

The study was conducted at Halaba special woreda in Southern nations and nationalities, and people's Region (SNNPR). It is $85 \mathrm{~km}$ away from the region's capital, Hawassa and $315 \mathrm{~km}$ from Addis Ababa. The area lies 1800 meter above sea level with annual rainfall of $857 \mathrm{~mm}-$ $1085 \mathrm{~mm}$ and in a bimodal pattern with small rains between March and April and main rainfall from July to October. There are three distinct seasons, dry, short rain, and long rain season and 
the average temperature ranges from $17^{0} \mathrm{c}-20^{\circ} \mathrm{c}$. The major crop gown in the area includes maize, Sorghum, Teff, Finger millet, wheat, and Chat. Maize is a major crop grown throughout the study site. Cattle, Goats, Sheep, Donkeys and poultry are the major livestock species found in the woreda. According to census made during 2004 E.C the population of Halaba is estimated Male $147,000 \&$ Female 124,000 Total Estimated to be 271,000 \& the main language Spoken by society in the area is Halabigna The livestock population of the area was about 252597 cattle,161197 shot, 44195 Equines and 157584 poultry [6].

\subsection{STUDY DESIGN}

A cross sectional study was conducted from November 2015-March 2016 to determine the prevalence and associated risk factors of bovine fasciolosis in Halaba Special Woreda.

\subsection{STUDY POPULATION AND SAMPLING TECHNIQUE}

The study populations were cattle of different ages and body conditions brought from the surrounding areas of Kambata and silteto the abattoir for the purpose of meat production. Simple random sampling method was used to select the study animals.

\subsection{SAMPLE SIZE DETERMINATION}

Since there was no earlier work done on prevalence and associated risk factors of bovine fasciolosis at the study area, the sample size was determined by taking the prevalence of $50 \%$ fasciolosis using the formula given by [25]

$$
\mathrm{n}=\frac{(1.96) 2 * \operatorname{Pexp}^{*}(1-\operatorname{Pexp})}{\mathrm{d}^{2}}
$$

Where, $\mathrm{n}=$ required sample size, Pexp=expected prevalence, $\mathrm{d} 2=$ Desired absolute precision confidence level $=95 \%$ accordingly, 384 cattle were sampled from the cattle brought to the Halaba municipal abattoirfor slaughter during the study period.

\subsection{ANTI-MORTEM EXAMINATION}

During ant mortem examination detail records about the age, breeds, sex, and body condition of animals was recorded.

\subsection{POSTMORTEM EXAMINATION AND FASCIOLA SPECIES IDENTIFICATION}

During postmortem inspection, each liver was visually inspected, palpated, and bile duct incised based on routine meat inspection the gall bladder was then separated from the liver, emptied and washed in to a glass trough and the contents of the trough were checked for adult and immature Fasciola parasites The bile ducts were opened with scissors and searched for flukes. The liver was then cut into $1 \mathrm{~cm}$ thick slices and pressed between the fingers to expose flukes lodged in the small bile ducts. The numbers of heads recovered in this way were counted and recorded [14]. 
After collecting the flukes in the universal bottle containing 5\% formalin as a preservative, Fasciola species were easily identified based on morphological characters such as shape, size. They were classified as Fasciola hepatica (relatively small sized), Fasciolagigantica (relatively large sized and more leaf like), mixed forms (Fasciola hepatica and Fasciolagigantica) and undifferentiated or immature (juveniles) forms of Fasciola species [27].

\subsection{DATA MANAGEMENT AND ANALYSIS}

The raw data generated from the study were entered into Microsoft Excel database organized and arranged using Microsoft Excel spread sheet computer program and were imported to be analyzed by STATA Version 7.0. Descriptive statistics was computed. Odd ratios were used to determine the statistical association between ages, sex, breed and body condition. A statistically significant association between variables was considered to exist if the calculated p-value is less than 0.05 with $95 \%$ confidence level.

\section{RESULTS}

Of the total 384 slaughtered cattle that subjected to detailed postmortem examination at Halaba municipal Abattoir, 38 were positive for fasciolosis with $9.88 \%$ prevalence and $95 \%$ confidence interval [0.071-0.133] (Table 1 ). The highest prevalence was recorded in old age (12.6\%), male (10.6\%), poor body condition (33.3\%), and Holstein Friesian breed (20.0\%) (Table1).

Table 1: The effect of the risk factors for fasciola infection using multivariate logistic regeration

\begin{tabular}{|c|c|c|c|c|c|c|}
\hline Variable & $\begin{array}{l}\text { No } \\
\text { animals } \\
\text { sample }\end{array}$ & $\begin{array}{ll}\text { No. } & \text { of } \\
\text { positive } & \end{array}$ & $\begin{array}{l}\text { Prevalence } \\
(\%)\end{array}$ & OR & P-value & {$\left[\begin{array}{lll}95 \% & \mathrm{CI}\end{array}\right]$} \\
\hline \multicolumn{7}{|l|}{ Age } \\
\hline Adult & 193 & 14 & 7.3 & 1.458 & 0.352 & [0.658-3.226] \\
\hline Old & 191 & 24 & 12.6 & $*$ & & \\
\hline \multicolumn{7}{|l|}{ Sex } \\
\hline Female & 74 & 5 & 6.8 & $*$ & & \\
\hline Male & 310 & 33 & 10.6 & 1.793 & 0.286 & [0.613-5.241] \\
\hline \multicolumn{7}{|l|}{ Body } \\
\hline \multicolumn{7}{|c|}{ Condition } \\
\hline Poor & 84 & 28 & 33.3 & $*$ & & \\
\hline Medium & 138 & 6 & 4.34 & 0.091 & 0.000 & {$[0.035-0.236]$} \\
\hline Good & 162 & 4 & 2.46 & 0.044 & 0.000 & {$[0.014-0.135]$} \\
\hline \multicolumn{7}{|l|}{ Breed } \\
\hline Local & 335 & 29 & 8.7 & $*$ & & \\
\hline Cross & 24 & 4 & 16.7 & 2.402 & 0.223 & [0.587-9.827] \\
\hline $\begin{array}{l}\text { Holstein } \\
\text { Eriesian }\end{array}$ & 25 & 5 & 20.0 & 3.091 & 0.089 & [0.841-11.361] \\
\hline
\end{tabular}

\section{Total}

From the total of 384 slaughtered animals whose liver were inspected in the abattoir, 38 livers were found to be positive for liver fluke infection (Table 2) and from these 9 livers $(2.34 \%)$ 
harbored with F.Hepatica, 14 livers (3.64\%) harbored with F.gigantica, 8 livers (2.08\%) harbored with mixed infection and the remaining 7 livers $(1.82 \%)$ were harbored with immature liver flukes. F. gigantica was seen to be more prevalent than F. hepatica (Table 2).

Table 2: Prevalence of bovine fasciolosis in slaughtered cattle at Halaba municipality abattoir by

\begin{tabular}{lll}
\multicolumn{2}{c}{ fluke species } \\
\hline Species & No. of livers infected & Prevalence (\%) \\
\hline F.hepatica & 9 & 2.34 \\
F. gigantic & 14 & 3.64 \\
Mixed & 8 & 2.08 \\
Immature & 7 & 1.82 \\
\hline Total & 38 & 9.88 \\
\hline
\end{tabular}

The risk of fasciola infection was significantly higher in poor body condition animals than in medium and good body condition animals ( $\mathrm{p}<0.05)$. However, in terms of age, sex and breed, no statistically significant difference was found between infected animals $(\mathrm{p}>0.05)$.

Table 3: Abattoir prevalence of bovine fasciolosis by associated risk factors in relation to fluke species

\begin{tabular}{|c|c|c|c|c|c|c|c|}
\hline \multirow[t]{2}{*}{ Variables } & \multirow{2}{*}{$\begin{array}{l}\text { Total } \\
\text { examined }\end{array}$} & \multicolumn{6}{|c|}{ Prevalence in \% } \\
\hline & & F.gigantica & F.hepatica & Mixed & Immature & OR & P-value \\
\hline \multicolumn{8}{|l|}{ Sex } \\
\hline Female & 74 & $1(1.35 \%)$ & $1(1.35 \%)$ & $1(1.35 \%)$ & $2(2.7 \%)$ & $*$ & \\
\hline Male & 310 & $13(4.19 \%)$ & $8(2.58 \%)$ & $7(2.25 \%)$ & $5(1.61 \%)$ & 1.793 & 0.286 \\
\hline \multicolumn{8}{|l|}{ Age } \\
\hline Adult & 193 & $2(1.03 \%)$ & $4(2.07 \%)$ & $4(2.07 \%)$ & $4(2.07)$ & 1.458 & 0.352 \\
\hline Old & 191 & $12(6.28 \%)$ & $5(2.61 \%)$ & $4(2.09 \%)$ & $3(1.57 \%)$ & $*$ & \\
\hline \multicolumn{8}{|l|}{$\begin{array}{l}\text { Body } \\
\text { condition }\end{array}$} \\
\hline Poor & 84 & $10(11.9 \%)$ & $5(5.95 \%)$ & $8(9.52 \%)$ & $5(5.95 \%)$ & $*$ & \\
\hline Medium & 138 & $1(0.72 \%)$ & $4(2.89 \%)$ & 0 & $1(0.72 \%)$ & 0.091 & 0.000 \\
\hline Good & 162 & $3(1.85 \%)$ & 0 & 0 & $1(0.61 \%)$ & 0.044 & 0.000 \\
\hline \multicolumn{8}{|l|}{ Breed } \\
\hline Local & 335 & $10(2.98 \%)$ & $8(2.38 \%)$ & $5(1.49 \%)$ & $6(1.79 \%)$ & $*$ & \\
\hline Cross & 24 & $2(8.34 \%)$ & 0 & $2(8.34 \%)$ & 0 & 2.402 & 0.223 \\
\hline $\begin{array}{l}\text { Holstein } \\
\text { Frisian }\end{array}$ & 25 & $2(8 \%)$ & $1(4 \%)$ & $1(4 \%)$ & $1(4 \%)$ & 3.091 & 0.089 \\
\hline Total & 384 & & & & & & \\
\hline
\end{tabular}




\section{DISCUSSION}

Fasciolosis is an important parasitic disease of domestic ruminants caused by two liver fluke species: Fasciola hepatica and F. gigantica (Trematoda). Fasciola hepatica has a cosmopolitan distribution, mainly in temperate zones, while F. gigantica is found in tropical regions of Africa and Asia. Bovine fasciolosis exists in almost all region of Ethiopia. However, the prevalence, epidemiology and Fasciola species involved vary with locality. This is mainly attributed to the variation in the climate and ecological condition such as altitude, rainfall, temperature and livestock management system [5].

The overall prevalence of fasciolosis in cattle recorded in this study (9.88\%) was lower than previous reports of 14\% by [3] from Soddo, 20.3\% by[ 9] from Addis Ababa abattoir, 46.6\% from Jimma [26], 26\%, from Kenya [16], 46\% from Zambia [19] and 14.1\% from Tanzania [23]. It was also higher than the prevalence of $8 \%$ from Nigeria [17]. The variation in overall prevalence of bovine fasciolosis among different areas of the study may depend on some factors such as, snail population, livestock management system and suitability of the environment for survival and distribution of the parasite as well as the intermediate host might have played their own role in such differences [29].

The body condition of the cattle was strongly associated $(\mathrm{P}<0.005)$ with risk of infection. Accordingly, cattle with poor body condition $(\mathrm{OR}=1)$ showed higher prevalence of fasciolosis than cattle with medium $(\mathrm{OR}=0.09195 \% \mathrm{CI}=0.035-0.236)$ and good body condition $(\mathrm{OR}=0.044$ $95 \% \mathrm{CI}=0.014-0.135)$. Similar finding was also reported by [1]. This is due to body condition is intimately related to animal's health, quality or vigor and has been widely claimed to be an important determinant of fitness. This implies that fasciolosis causes emaciation of the animals. Low body score was associated with liver fluke infection. However, other than fluke infection, inadequate nutrition and concurrent infection of the animals with other bovine pathogens could enhance the effects of the flukes for the emaciation of the animals.

The present finding revealed that F. gigantica was more prevalent than F. hepatica at the study abattoir. Similar findings had been reported by [4] affirmed that F. gigantica was the most common liver fluke species affecting cattle at Wolayta Soddo municipal abattoir in Southern Ethiopia. Similarly studies conducted in Zambia, [18, Kenya28; 16 and Europe 12].reported F. gigantica as the most common species infecting cattle. One of the most important factors that influence the occurrence of fasciolosis in an area is the availability of a suitable habitat for the snail intermediate hosts [27].In addition, optimal base temperature to levels of $10{ }^{\circ} \mathrm{C}$ and $16{ }^{0} \mathrm{C}$ are necessary for the snail vectors of Fasciola hepatica and Fasciolagigantica, respectively. The ideal moisture conditions for snail breeding and development of larval stages within the snails are provided when rainfall exceeds transpiration and field saturation is attained. Such conditions are also essential for the development of fluke eggs and miracidae searching for snails and dispersal of cercariae [27].

The results of the present study revealed that sex have no significant effect on the prevalence of bovine fasciolosis. This is in agreement with several previous reports in different parts of the countries $[10 ; 18 ; 11 ; 7 ; 8]$. This could be associated with similar management given to both male and females cattle. In communal grazing areas, both females and males graze on the same 
pasture and move in searching of food and water together, which expose to the same risk of infection. Moreover, it might also be that fasciolosis is not a disease directly related to animal reproductive system. However,male cattle were $(\mathrm{OR}=1.793)(95 \% \mathrm{CI}=0.613-5.241)$ times more likely in harboringinfection as compared to females . This might be attributed to the management system with longer exposure of male outdoor when females are kept indoor at the beginning of lactation.

In the present study,agehave no significant effect on the prevalence of bovine fasciolosis. This could be due to the fact that both adult and older cattle were forced to graze on the same pasture, exposed to risk of infection by metacercaria of Fasciola species. This corroborates with other previous findings $[18 ; 11 ; 2]$.However, old cattle were more likely in developing fasciolosis to be infected as compared to adults. This could be the decrease of immunity in aged animals rather than adults who attain their maximum immunity.

In the present study, there was no statistically significant association $(\mathrm{P}>0.05)$ between the breeds of cattle and prevalence of fasciola infection. This is in agreement with many earlier research findings $[21 ; 29 ; 8]$. However, a higher prevalence of fasciolosis was observed in Holstein breed $(20 \%)(\mathrm{OR}=3.09195 \% \mathrm{CI}=0.841-11.361)$ followed by Cross breed $(16.7 \%)$ $(\mathrm{OR}=2.40295 \% \mathrm{CI}=0.587-9.827)$ and local breed $(8.7 \%)$. This could be explained by the fact that, the higher prevalence rate in Holstein breed and followed by cross-breed may be due to the less adaptively capacity with the environment and Indigenous breeds are acquired a high degree of immunity as a result of repeated natural exposure to parasitic infections. This is related with the management of the cattle in this area. All these cattle breeds graze on cultivated and natural pastures.

It was difficult to trace the exact geographical origin of the animals slaughtered in the municipal abattoir as most of the cattle were brought from markets. Based on information acquired from the traders and farmers, most of the animals are local indigenous zebu cattle originated from various grazing areas of Halaba and neighboring woredas. Significant numbers of cattle were originated from areas of the woreda where small irrigation practices implemented which might support suitable snail breeding habitats that results in the existence of Fasciola species which causes infection of animals originated from these areas.

\section{CONCLUSION AND RECOMMENDATIONS}

The current study assessed the prevalence of Bovine fasciolosis, predominant species of fasciola and its associated risk factors and found lower prevalence in the study area. The prevalence of infection rate was found higher in animals with poor body condition than medium and good body condition. Therefore, body condition was found to be important risk factor associated with fasciola infection. Whereas age, sex and breed were had no association with fasciola infestation in studyanimals. Based on the result, the most predominant fasciola species in the study area was $F$. gigantica which might be due to suitability of the environment for multiplication of the intermediate host. Different activities such as irrigation and ponds in some parts of study area contribute for the current finding. The present study showed that bovine fasciolosis is one of the important pathogens in cattle in the study area and warrants appropriate disease prevention and 
control measures and further epidemiological investigations to determine the different agro ecological risk factors on the occurrence of the disease.

\section{REFERENCES}

[1] Bekele, M., Haftom, T \&Yehenew, G. Bovine fasciolosis: Prevalence and its economic loss due to liver condemnation at Adwa municipal abattoir, North Ethiopia. Ethiopian Journal of Agricultural Science and Technology, 1, 2010, 39-47.

[2] Elkannah, O.S. Preliminary studies on fasciolosis in cattle slaughtered Atjalingo abattoir, Taraba state. Nigerian Journal of Science, Technology and Environmental Education, 3, 2010, 143-146.

[3] Fufa Abunna, Lome Asfaw, BekeleMegersa and AlemayehuRegassa, Bovine fasciolosis: coprological, abattoir survey and its economic impact due to liver condemnation at Soddo Municipal abattoir. Southern Ethiopia. Tropical Animal Health and Production, 42, 2010, 289-292.

[4] Fufa, A., Loma, A., Bekele, M \& Alemayehu, R. Bovine fasciolosis: Carpological, abattoir survey and its economic impact due to liver condemnation at Soddo municipal abattoir, Southern Ethiopia. Tropical Animal Health Production 42, 2009, 289-292.

[5] Essubalew Getachew, Eba Abraham, and Wendimu Melese, "Growth Response Of Broccoli (Brassica Oleracea) To Different Planting Date At Jimma South Western Ethiopia” International Journal of Research - Granthaalayah, Vol. 4, No. 6 (2016): 110118.

[6] Graber, M. Helminthes and Helminthiasis of Domestic and wild animal of Ethiopia.Bulletin of Animal Health and prd.In Africa, 23, 1978, 57-86.

[7] Halaba special woreda Office of Agriculture, (2015).Back ground information and location of Halaba special woreda unpublished, pp. 11-13.

[8] Kabir, M.H., Eliyas, M., Hashem, M.A \& Miazi, O. F. Prevalence of zoonotic parasitic diseases of domestic animals in different abattoir of Comilla and Brahman Baria region in Bangladesh. Journal of zoology 28, 2010, 21-25.

[9] Kanyari, P.W., Kagira, J. M \&Mhoma, R. J. Prevalence of endoparasites in cattle with zoonotic potential within urban and peri-urban areas of Lake Victoria Basin, Kenya.Journal Animal and Biomedical Science, 4,2010,26-33.

[10] Kassaye Aragaw, Yehualashet Negus, YifatDenbarga and DesieSheferaw, Fasciolosis in Slaughtered Cattle in Addis Ababa Abattoir, Ethiopia. Global Veterinarian, 8, 2012, 115 118.

[11] Keyyu, J., Monrad, J., Kyvsgaard, $N \&$ Kassuku, A. Epidemiology of Fasciolagigantica and Amphistomes in cattle on traditional, small-scale dairy and large-scale dairy farms in the Southern highlands of Tanzania.Tropical Animal Health and Production, 37,2005,303-314.

[12] Khan, M.K., Sajid, M.S., Iqbal, Z \&Iqbal, M.U. Bovine fasciolosis prevalence, effects of treatment on productivity and cost benefit analysis in five districts of Punjab, Pakistan. Research Veterinary Science, 87, 2009, 70-75.

[13] Mage, C., Bourgne, H., Toullien, J.M., Rondelaud, D., Drefuss, G., .Fasciola hepatica and Paramphistomumdaubneyi: changes in prevalences of natural infections in cattle and in Lymnaeatruncatula from central France over 12 years. Veterinary Research, 33, 2002, 439-447. 
[14] Abebe Woldesenbet, Abreham Wolde, and Ayele Tefera, "Effects Of Wild Oat (Avena Fatua L.) Density On Wheat (Triticum Eastivum L.). Yield And Yield Components" International Journal of Research - Granthaalayah, Vol. 4, No. 9 (2016): 124-130.

[15] Malone JB, Gomes R, Hannen J, et al. Geographical information system on the potential distribution and abundance of Fasciola hepatica and Fasciolagigantic in east Africa based on food and Agriculture Organization data base. Vet Parasitol78, 1989 ,87-101.

[16] Manyazewal Anberber Zeleke, Mengistu Gurmesa and Tsegaye TesfayeEconomic Significance of Fasciolosis at Mettu Municipal Abattoir, Southwest Ethiopia,Journal of Advanced Veterinary Research 4 (2),2014, 53-59.

[17] Michael, A. (2004). Infectious Prevalence of Ovine Fasciolosis in Irrigation Schemes along The Upper Awash River Basin and Effect of Strategic Anthelmintic Treatment in Selected up Stream Areas. M.Sc. Thesis, Department of Biology, School of Graduate Studies, Addis Ababa University, Addis Ababa.,P 78.

[18] Mungube, E.O., Bauni, S.M., Tenhagen, B.A., Wamae, L.W., Nginyi, J.M., Mugambi, J.M., The prevalence and economic significance of Fasciolagigantica and Stilesia hepatica in slaughtered animals in the semiarid coastal Kenya.Tropical Animal Health and Production,38,2006,475-483.

[19] Okoli, I.C., Agoh, E.C., Okoli, G.C., Idemi, G.C., Umesiobi, D.O., Bovine and Caprinefasciolosis in Enugu State of Nigeria: Retrospective analysis of abattoir records (1983- 1997) and six-month prevalence study.JournalofBulletin of Animal Health Production Africa,48,2000, 7-11

[20] Phiri, A. M., Phiri, I. K., Sikasunge, C.S \&Monrad, J. Prevalence of fasciolosis in Zambian cattle observed at selected abattoirs with emphasis on age, sex and origin. Journal Veterinary Medicine, 52, 2005, 414-416.

[21] Phiri, A.M.,. Common conditions leading to cattle carcasses and offal condemnations at 3 abattoirs in Western Province of Zambia and their zoonotic implications to consumers. Journal of South African Veterinary Association 77(1), 2006,28-32.

[22] Haile Terefe, EwnetuDenberu, and Abebe Woldesenbet, "Effects Of Different Weeding Time Of Ryegrass On Growth And Yield Components Of Wheat (Triticum Spp.) In Jimma Are, South West Ethiopia” International Journal of Research - Granthaalayah, Vol. 4, No. 10 (2016): 111-117

[23] Rahmeto, A., Fufa, A., Mulugeta, B., Solomon, M., Bekele, M., Alemayehu, R. Fasciolosis: Prevalence, financial losses due to liver condemnation and evaluation of a simple sedimentation diagnostic technique in cattle slaughtered at Hawassa Municipal abattoir, southern Ethiopia Hawassa University, Faculty of Veterinary Medicine, Hawassa, Ethiopia. Ethiopian Journal ofVeterinary, 14, 2010,9-51.

[24] Sanchez-Andrade, R., Paz-Silva, A., Suárez, J.L., Panadero, R., Pedreira, J., López, C., Díez-Baños, $P \&$ Morrondo, P.. Influence of age and breed on natural bovine fasciolosis in an endemic area (Galicia, NW Spain). Veterinary Research Communication 26, 2002, 361-370.

[25] Sandra, M.T.M. and Maria, L.S. Fasciola hepatica infection in cattle and buffaloes in the state of Rio Granddosul, Journal of Brazil, 58,2003,169-172.

[26] Swai, E.S., Ulicky, E., .An evaluation of the economic losses resulting from condemnation of cattle livers and loss of carcass weight due to fasciolosis: a case study from Hai town abattoir, Kilimanjaro region, Tanzania. Livestock Research for Rural Development,21, 2009., 11- 186. 
[27] Tadele, T. and Worku, T. The Prevalence and Economic Significance of Bovine Fasciolosis at Jimma, Abattoir, Ethiopia..Internet Journal of Veterinary Medicine, 2, 2007, 1-7.

[28] Thrusfield, M., (2005).Veterinary Epidemiology 2nd ed. University of Edinburgh, Black well science. Pp. 180-188.

[29] Tolosa, T., Tigre, W., The prevalence and economic significance of bovine fasciolosis at Jimma abattoir, Ethiopia.The Internet Journal of Veterinary Medicine, 3, 2007,1 -7.

[30] Urquhart, G.M., Amour, J.L., Dunn, A.M. and Jennings, F.W. (1996).Veterinary Parasitology.2nd ed. Blackwell Publishing, Oxford, Pp: 105-112.

[31] Wamae, L.W., Hammond, J.A., Harrison, L.J.S., Onynago-Abuje, J.A., Comparison of production losses caused by chronic Fasciolagigantica infection in yearling Friesian and Borancattle.JournalofTropical Animal Health and Production, 30,1998, 23-30.

[32] Wendimu Melese, "Effect Of Farm Yard Manure Application Rate On Yield And Yield Components Of Lettuce (Lactuca Sativa) At Jimma Southwestern Ethiopia” International Journal of Research - Granthaalayah, Vol. 4, No. 8 (2016): 75-83.

[33] Yildirim, A., A. Ica, O. Duzlu, and A. Inci,. Prevalence and risk factors associated with Fasciola hepatica in cattle from Kayseri province, Turkey. Journal of Revue Medical Veterinary, 12, 2007, 613-617.

[34] Roba Tufa, and Jima Nego, "Effects Of Seed Priming With Sodium Chloride On Seedling Performance Of Common Bean (Phaseolus Vulgaris L.) Under Green House Condition” International Journal of Research - Granthaalayah, Vol. 4, No. 6 (2016): 222-228.

[35] Yilma, J. and Malones, J.B. A geographical information system forces model for strategic control of fasciolosis in Ethiopia. Veterinary Parasitology, 78, 1998, 103-127. 